\title{
Csípőprotézis revíziókról - 1065 eset alapján
}

\author{
DR. UDVARHELYI IVÁN ${ }^{1}$, DR. KÁLLAY TAMÁS ${ }^{1}$, DR. SZILY TAMÁS ${ }^{1}$, \\ DR. MÁTYÁS VIKTOR ${ }^{1}$, DR. ABONYI BENCE ${ }^{1}$, DR. HANGODY LÁSZLÓ ${ }^{1,2}$
}

\section{ÖSSZEFOGLALÁS}

A csípőprotézis revíziók száma évről évre emelkedik. Ennek okaként számos tényezőt feltételeznek. Az esetszám növekedését mindenekelőtt az egyre nagyobb számban, egyre fiatalabb életkorban és sajnos nem mindig megfelelő minőségben elvégzett primer beültetés okozhatja. Az irodalmi adatok és szerzők gyakorlata alapján a cementnélküli revíziók dominanciája egyértelmű, ennek indikációs feltételrendszere, mútéttechnikai megfontolások és rövid, illetve középtávú eredményei a technikát igazolják. Intézetükben 2001 és 2017 között elvégzett 1065 csípőrevíziós mútét eredményei a cementnélküli revíziók növekvő létjogosultságát igazolják, amit a korszerű és egyre növekvő indikációval, akár súlyos defektusban is megbízható beültetést lehetővé tevő grafttechnikák és implantátumok támogatnak.

\section{Kulcsszavak: $\quad$ Csípöprotézis revizió; Csontátültetést; Rekonstrukciós mütét; Reoperáció; Utánkövetéses vizsgálat;}

I. Udvarhelyi, T. Kállay, T. Szily, V. Mátyás, B. Abonyi, L. Hangody: Revision total hip arthroplasty - based on 1065 cases

Continuous increase in number of revision total hip arthroplasty is seen year by year. It's generally agreed, that the multiple reason include facts like elevating number of primary implantations performed in younger ages of patients, unfortunately not always following standards of perfect quality. Literature and authors' series of patients refer to dominancy of uncemented revisions supported by appropriate algorythm of indication, operation technique, and short, mid term results. Results of 1065 total hip revisions operated in their institute between 2001 and 2017 foster prevalence of uncemented revisions supported by wide range of graft techniques and selection of modern implants making the technique suitable to use in various indications and significant bone defects.

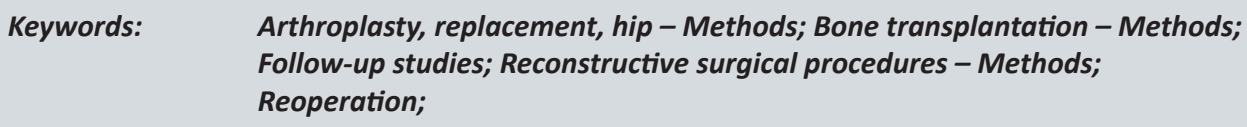




\section{BEVEZETÉS}

A csípőprotézis revíziók száma évről évre jelentős mértékben növekszik. Ennek egyik oka az egyre nagyobb számban és egyre fiatalabb életkorban elvégzett csípő arthroplasticák. A korszerű kialakítású és bevonatolású cementnélküli implantátumok nagymértékben megnövelték a protézis túlélést $(20,41)$. Számtalan egyéb tribológiai és fejméret elmélet mentén a protézis lazulás rátája tovább csökkenthető. Mára egyértelmúvé vált - és ezt a legtöbb regiszter adatai alátámasztják - hogy a cementnélküli implantátumok túlélése jobb, mint a cementezetteké $(17,19)$, bár - megfelelő csontminőség és cementezési technika esetén - ezt az adatot néhány cementezett implantátum túlélése részben megcáfolja. Alapvető fontosságú a primer beültetések esetén a maximális tökéletességre való törekvés, ez elsősorban az anatómia, ezen belül is a csípő forgáscentrum pontos helyreállítását jelenti $(3,15)$. Természetesen ezt támogatja az implantátum megfelelő biomechanikával és tribológiával.

A revíziós arthroplastica nemcsak jóval nagyobb tapasztalatot és felkészültséget igényel, de a legtöbb esetben nehéz előre determinálni az adott betegnek - a többször eltérő opciók közül - a legmegfelelőbb megoldást, amely a revíziós mútét lehető leghosszabb, a beteg számára használható túlélését eredményezi (4-6, 8-10, 33, 38, 40). A revíziók nagy hányadában olyan mértékú defektust találunk - sajnos legtöbbször a nem időben elvégzett mútét miatt - ami még speciális kialakítású implantátum használatával is kérdésessé teszi a hosszú távú jó eredményt $(1,11,12,16,18,26,35)$. Soha ne feledkezzünk meg a szekunder Girdlestone helyzet kialakításának lehetőségéről, amely sokkal többet ér, mint egy használhatatlan revízió.

\section{ANYAG ÉS MÓDSZER}

Elengedhetetlen a megfelelő és a megoldás tekintetében iránymutató klasszifikációk használata. Ezt mind a vápa, mind a szárdestrukció vonatkozásában szükséges elvégezni. Minden esetben ajánlatos indikációs és tervezési algoritmus használata. A fizikális vizsgálat kiterjed a kontraktúrák (elsősorban flexiós és addukciós kontraktúra) meghatározására
- ez következtetni enged a csont destrukció fő irányára és a feltárás nehézségeire. Standard röntgenfelvételek álljanak rendelkezésre, amelyeken láthatók a rekonstrukció fő iránymutatói, végtaghossz és offset eltérések. Végezhetünk egyéb képalkotó eljárásokat, 3D CT vizsgálatot, amely hasznos információkat tartalmazhat a destrukció mértékéről, azonban nem mindenható, különösen nem a megmaradó csont minőségét illetően. Célszerű ismerni az előző feltárást, ugyanis gyakran új irányból hatolunk be, minden esetben a maximális célravezetőséget szem előtt tartva.

Intézetünkben minden esetben anterolateralis Watson-Jones feltárást alkalmaztunk. A feltárás során a protézis luxálása után a szár feltárásával kezdünk. Ennek oka, hogy a szár feltárásakor elvégzett Müller-féle „fossa trochanterica release” nemcsak a szár és az esetleges cementeltávolítás vizualizálhatóságát növeli, csökkenti az intraoperatív periprotetikus törés veszélyét, de a későbbiekben a vápafeltárást is megkönnyíti a kiterjedt postero-medialis hegeltávolítás lehetősége miatt. A mútét során fontos, hogy rendelkezésre álljon csontpótláshoz szükséges fagyasztott allograft, tantalum augmentációs készlet és teljes vápa és szár revíziós arzenál.

Az indikáció felállításánál szükséges a lazulás okának ismerete:
1. vápa vagy szár malpozíció
2. impingement
3. protézis instabilitás
4. polyethilen kopás
5. progresszív protrusio
6. osteolysis
7. periprotetikus törés

Bármilyen eredetet véleményezünk, minden esetben szükséges az infekciós eredet kizárása, különös tekintettel a low-grade infekciós esetekre.

A revíziók elsődleges célja a meglévő csontállomány lehető legnagyobb mértékű megőrzése, amely biztosítja a beültetendő revíziós implantátum stabilitását. A csontállomány lehetőség szerint biológiai (1-2. ábra), szükség esetén implantáris rekonstrukciójára is sor kerülhet (3-5. ábra). Az anatómia, a csípő forgáscentrum, és implantátum tengely lehető legnagyobb mértékú helyreállítása biztosítja a revideált ízület maximális, fájdalommentes stabilitását. 
Klasszifikáció tekintetében a legcélszerűbb a Paprosky féle beosztás használata mind a szár-, mind a vápadestrukció vonatkozásában.

Vápadestrukció: I. típus: intakt gyűrü, „contained" defektus. II. típus: részleges, kisebb mértékű gyűrü, vápafenék, vápatető laesio. III. típus: a): több, mint $3 \mathrm{~cm}$ ilium defektus, kevesebb, mint 50\% gyűrű defektus; b): több, mint $40 \%$ gyűrű defektus, jelentős hátsó oszlop defektus.

Revízió szempontjából a III. csoport jelenti a legnagyobb kihívást. A csípő anatómiában a postero-superior oszlop megléte kulcsfontosságú, ez képviseli a legnagyobb stabilitás tényezőt az ízület biomechanikájában.

A Paprosky féle szárdestrukció beosztás mérsékeltebb jelentőséggel bír. Amenynyiben a femur proximalis része megtartott és szupportiv, lehetséges moduláris rendszerű cementnélküli implantátum beültetése (6-7. ábra). Abban az esetben, ha a destrukció kiterjedtebb, a proximalis szupport hiányában kizárólag monoblokk szár használata lehetséges az implantátumtörés veszélye miatt. Intézetünkben kónikus kialakítású cementnélküli Wagner típusú szárakat használunk (ZMR, Wagner, Zimmer Corp., Warsaw, IN, USA).

Szárrevízió vonatkozásában a nehézséget a meglévő csontállomány megőrzése jelenti, különös tekintettel a cementes implantátumoknál a cementeltávolítás nehézségeire. Természetesen lehetséges trochanter osteotomia végzése, de ez a femur integritás csökkentése miatt a beültetendő revíziós szár stabilitását csökkenti. Célszerű - saját anyagunkban ezt alkalmazzuk - a röntgen képerősítő kontrollja alatt végzett centralizált-dilatációs fúrás technika használata. Ehhez a beültetendő kónikus revíziós szár merev fúró sorozata szükséges.

A nagyobb kihívást a vápa rekonstrukciója jelenti. Revíziók során jóval nagyobb számban találkozunk vápa lazulás és destrukció miatti indikációval. Forgástengely rekonstrukció tekintetében is a vápa kialakítása a döntő. $A$ feltárás során minden esetben a vápa alsó pólusát szükséges kipreparálni. Ez és a PA falszerkezet az elsődleges iránymutató a revíziós vápa felépítésében. A nem pontos forgáscentrumba beültetett vápa, a funkció közben fellépő egyenlőtlen tenziós erő eloszlás miatt, leggyakrabban a hátsó és felső fal pusztulását okozza. A nem időben elvégzett váparevízió a fokozatosan növekvő implantátum mobilitás következtében egyre kiterjedtebb destrukciót eredményez.

Paprosky I vápadestrukció eseteiben tekintettel arra, hogy „contained” defektussal állunk szemben, akár „impaction bone grafting”, akár cementnélküli tantalum borítású vápa (Trabecular Metal, Zimmer Corp., Warsaw, IN, USA), adott esetben a destrukció méretétől függően megavápa alkalmazása ajánlott. Megavápa és forgáscentrum emelés eseteiben a stabilitás érdekében szükséges a forgáscentrum emelés arányában az offsetet növelni.

Paprosky II vápadestrukció eseteiben a Paprosky I csoport protokollja alkalmazható, containment hiányában impaction bone grafting nem jön szóba.

Paprosky III destrukció esetén elengedhetetlen a hátsó oszlop rekonstrukciója, illetve a felső defektus pótlása. Ezt elvégezhetjük az előbbiekben említett megavápa technikával, azonban az úgynevezett "oblique" vápadefektussal járó csonthiányban szükséges a felső hiány csonttal való pótlása (1-2. ábra), vagy a nagyobb stabilitás érdekében felső augmentációk alkalmazása (3-5. ábra). Lehetséges „oblique” cementnélküli vápabeültetés, azonban ezen implantátumok esetében nehezebb a maximális kontaktussal bíró csontfelszín kiképzése. Az augmentáció alá ültethetünk tantalum felszínú revíziós vápát, vagy csontgraft kíséretében vápakosarat. Ezeknél az implantátumoknál szférikus marót használunk. Első és hátsó oszlop defektus eseteiben BurchSchneider vápakosár és csontgraft beültetése szükséges (8-9. ábra).

Teljes hátsó felső fal defektus eseteiben butress augment implantáció felmerül, azonban ennek tartóssága nem egyértelmü, Girdlestone helyzet megfontolandó.

Utánvizsgáltuk és összehasonlítottuk a 2001 és 2010 között, valamint 2011 és 2017 között elvégzett csípőrevíziós mútéteket, összesen 1065 esetet. Az első vizsgált időszakban 442, a második periódusban 623 csípőrevízió szerepel. Az utánvizsgálatban a Harris Hip Score-t alkalmaztuk. Értékeltük a röntgenfelvételeket, különös tekintettel a migrációra és a forgáscentrum változásra. 


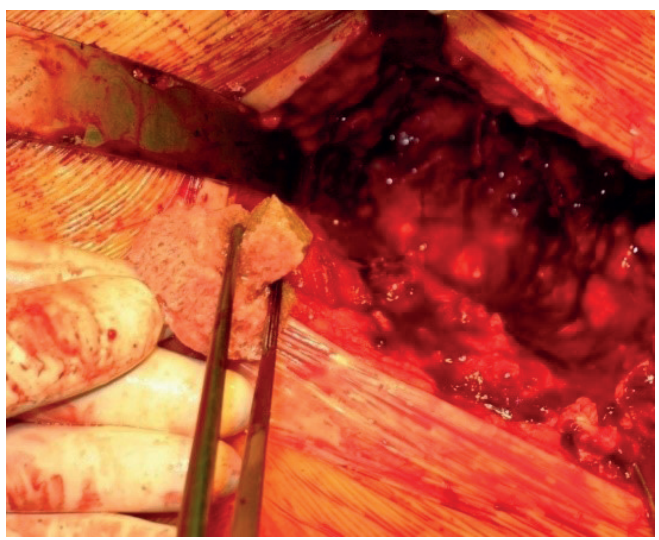

1. ábra Csípőprotézis revizió, vápadestrukció csontpótlás press-fit graft technikával

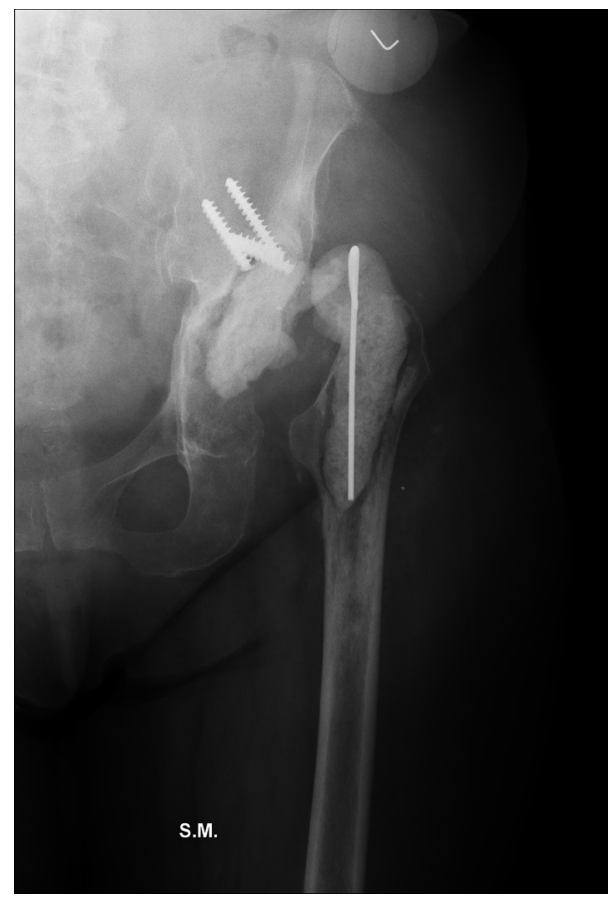

3. ábra Csípőprotézis kétlépcsős revizió kiterjedt PIIlb destrukcióban

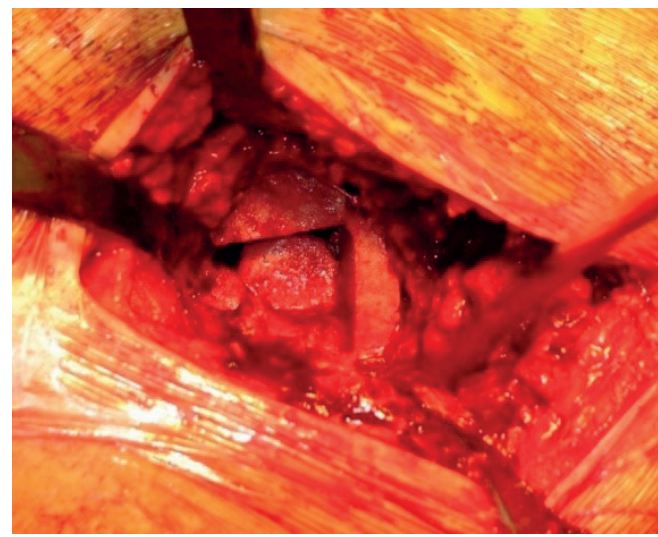

2. ábra Csípöprotézis revízió, vápadestrukció csontpótlás beültetett press-fit graftok

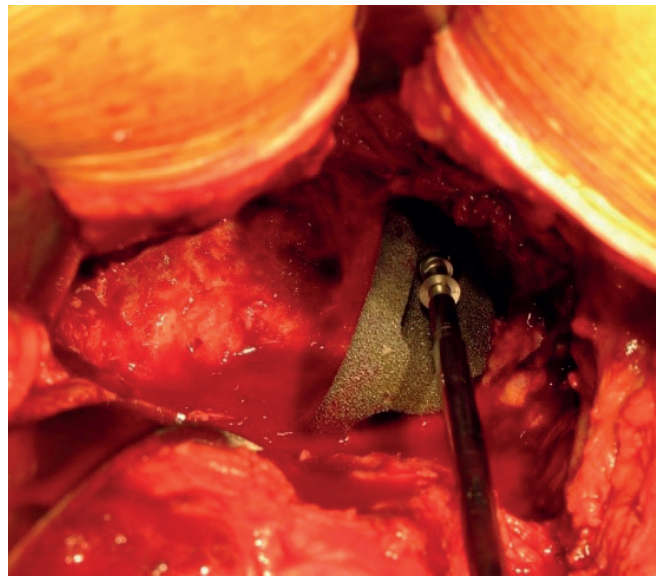

4. ábra Trabecular Metal augment felcsavarozása postero-superior defektusban 

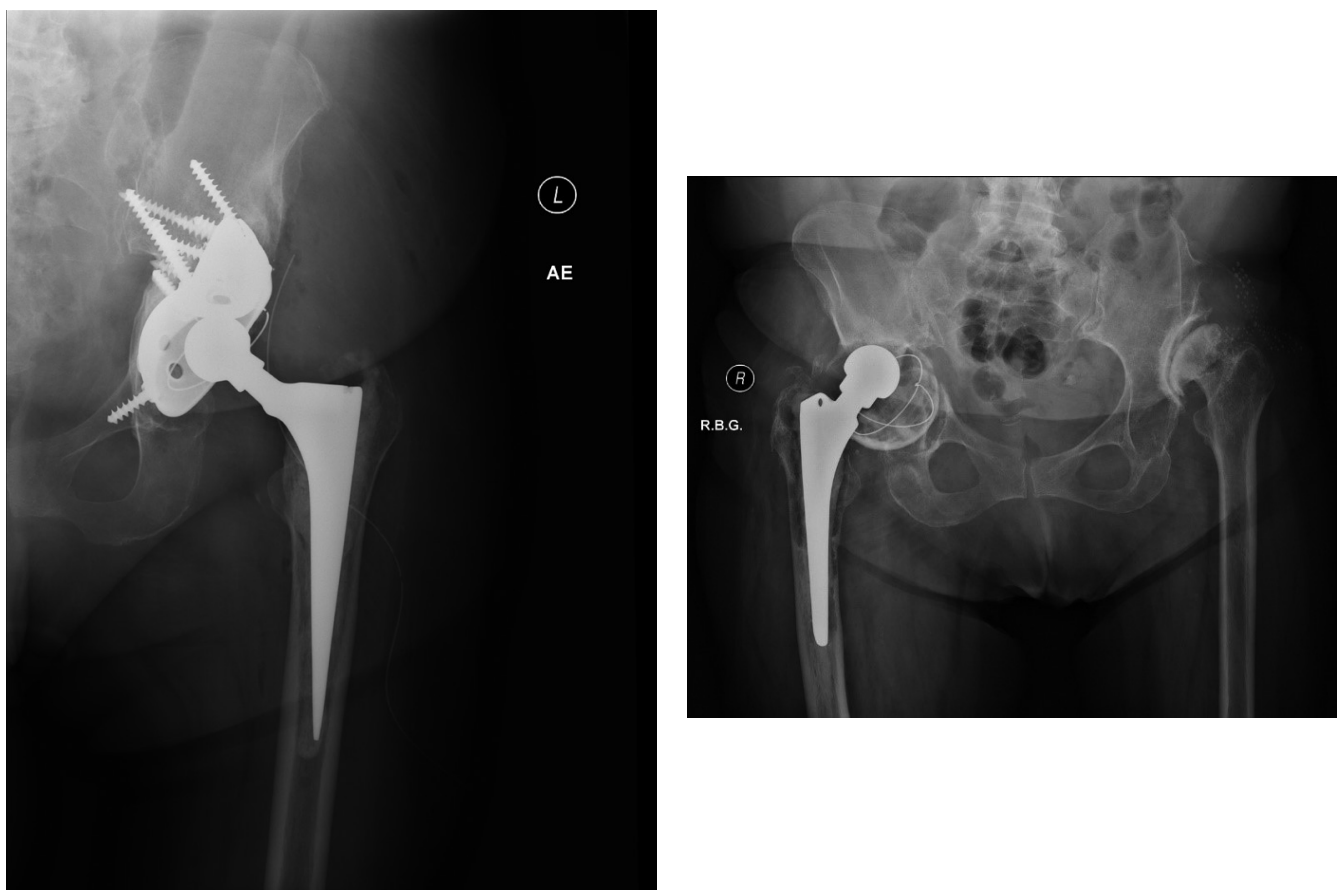

5. ábra Trabecular Metal augment + vápakosár rekonstrukció

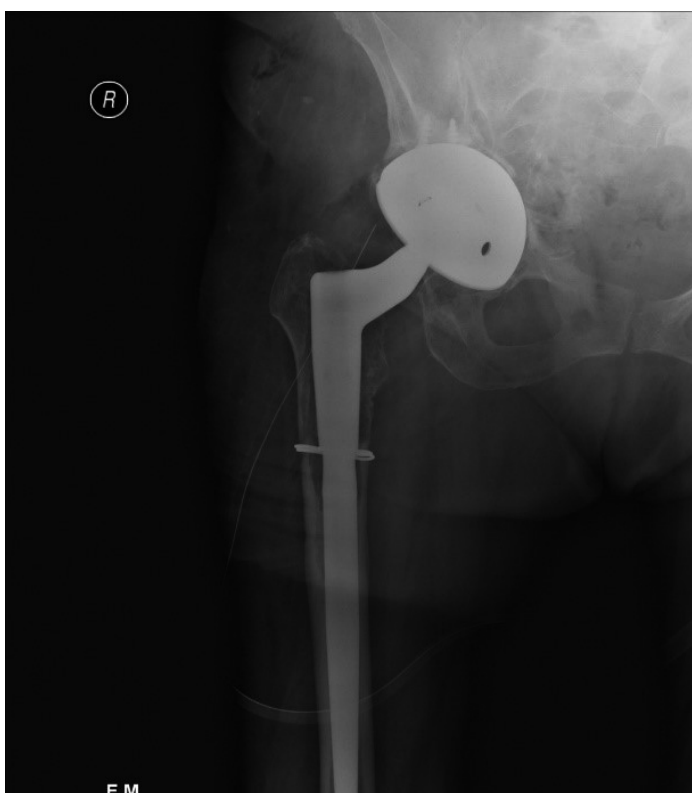

7. ábra Revízió TM shell vápa + ZMR szár beültetésével 


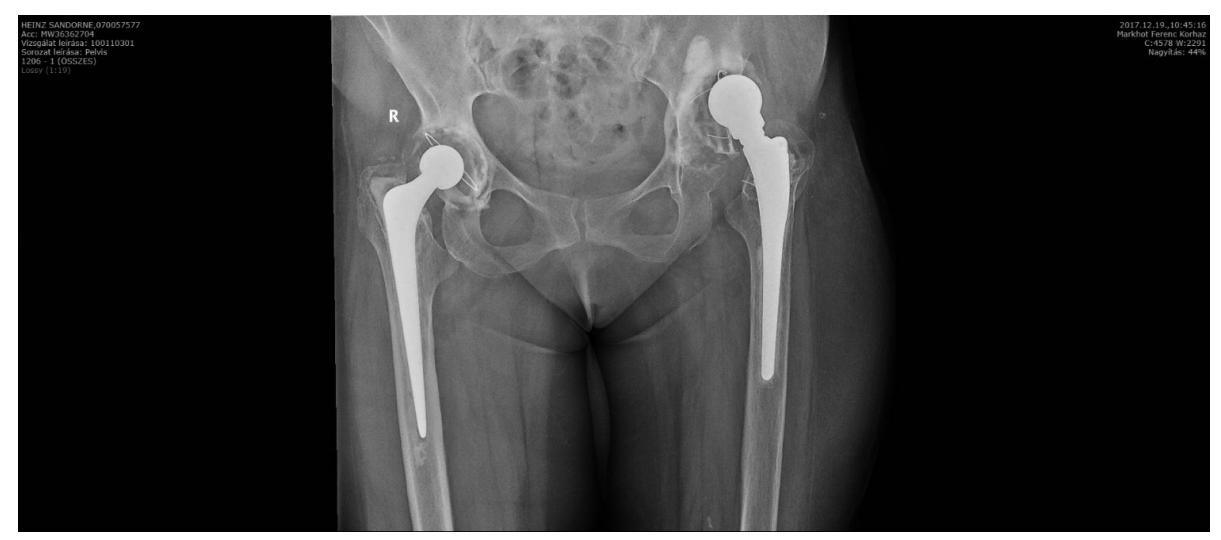

8. ábra Csípőprotézis vápa lazulás PIIlb vápadestrukció kiterjedt dorsosuperior csonthiánnyal

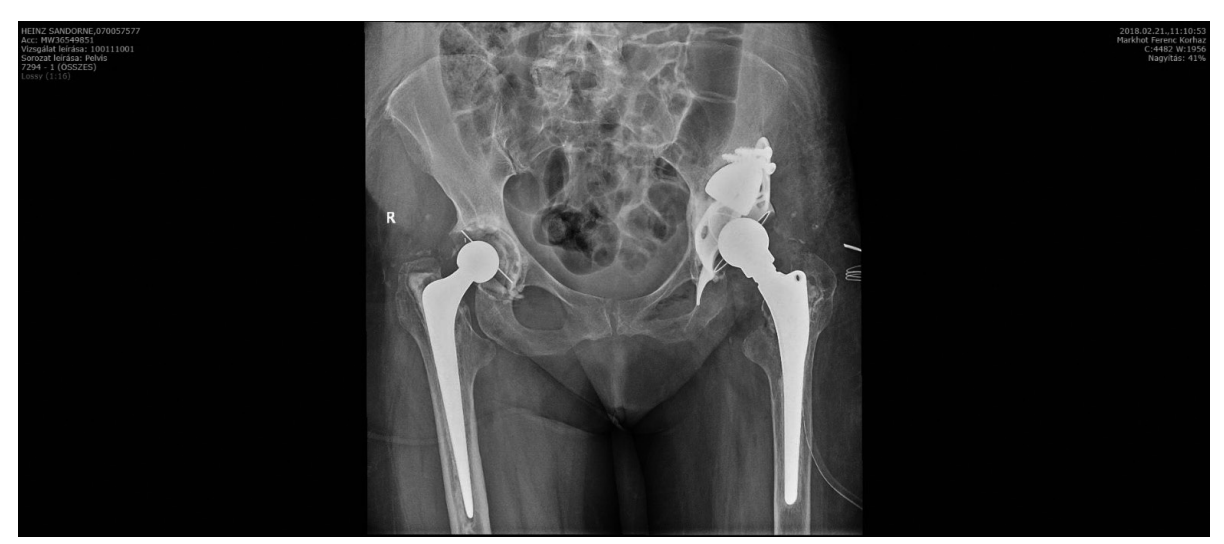

9. ábra Revízió TM augment + Burch-Schneider vápakosár beültetésével

\section{EREDMÉNYEK}

A vizsgált időszak vápa és szár revízió típusait az I. és II. táblázat részletezi. A táblázatok adataiból látható, hogy a két vizsgált időszakban a cementnélküli beültetések aránya mind a szár, de fóleg a vápa vonatkozásában jelentősen emelkedett. Az önálló szár revíziók aránya csökkent (26,4\% / 14,6\%). Az önálló váparevíziók aránya emelkedett (16,2\% / 21,8\%) Egy másik, osztályunkon elvégzett radiológiai utánvizsgálat a primer beültetések esetében a szár malpozíciók arányának csökkenését igazolta. (A revideált esetek mindössze 25,53\%ában állt rendelkezésre a primer beültetés posztoperatív röntgenfelvétele, amelyen bármilyen malpozíciót az esetek 41\%-ában észleltünk.)
Váparevíziók eseteiben a cementnélküli beültetések számának nagymértékű növekedése látható, elsősorban a tantalum bevonatolású revíziós vápák tekintetében. 17 alkalommal került sor augmentált vápa beültetésre. Paprosky IIIb destrukció eseteiben teljes dorsalis fal hiánya miatt buttress augmentációt nem használtunk. Szintén nem történt tantalum vápafenék pótlás, helyette strukturális press fit allograft beültetés, illetve 5 esetben tantalum felszínű úgynevezett shell vápába helyezett Burch-Schneider jellegü „cup cage” megoldás történt.

Radiológiai utánvizsgálat a preoperatív tervezés és a posztoperatív röntgenfelvétel viszonylatában, csípő forgáscentrum és offset tekintetében 92\%-os korrelációt igazolt. A maximális forgáscentrum emelés $3 \mathrm{~cm}$, átlagosan 
1,2 cm, ami megfelel a Harris által közölt értékeknek. Minden esetben az offset arányos növelése történt, részben a nagyobb méretű vápa, részben az emelt offset-tel rendelkező szár beültetésével. A posztoperatív infekciós ráta $0,56 \%$, a luxációs ráta $0,46 \%$ volt. Implantátum lazulás 1 éven beül 3 esetben történt ( 2 vápalazulás, 1 szármigráció). Utánvizsgálat a HHS szerint történt, a preoperatív 24-es érték a mútét után közvetlenül 74-re, majd 3 hónapos korban 91-re emelkedett.

\section{I. táblázat Csípőprotézis szárrevíziók megoszlása revizió típusa szerint}

\begin{tabular}{|c|c|c|c|c|c|c|c|}
\hline $\begin{array}{c}\text { Csípő } \\
\text { revízió }\end{array}$ & $\begin{array}{c}\text { CN szár } \\
\text { modularis }\end{array}$ & $\begin{array}{c}\text { CN szár } \\
\text { monoblock }\end{array}$ & $\begin{array}{c}\text { CN szár } \\
\text { reteszelt }\end{array}$ & $\begin{array}{c}\text { CN szár } \\
\text { Müller }\end{array}$ & $\begin{array}{c}\text { cementes } \\
\text { szár } \\
\text { revíziós }\end{array}$ & $\begin{array}{c}\text { cementes } \\
\text { szár } \\
\text { primer }\end{array}$ & $\begin{array}{c}\text { csak } \\
\text { szárrevízió }\end{array}$ \\
\hline $\begin{array}{c}2001-2010 \\
442 \text { beteg }\end{array}$ & 234 & 24 & 38 & 3 & 34 & 37 & 117 \\
\hline $\begin{array}{c}2011-2017 \\
623 \text { beteg }\end{array}$ & 394 & 27 & 11 & 9 & 38 & 8 & 91 \\
\hline
\end{tabular}

\section{II. táblázat Csípőprotézis váparevíziók megoszlása revizió típusa szerint}

\begin{tabular}{|c|c|c|c|c|c|c|c|c|}
\hline $\begin{array}{c}\text { Csípőre- } \\
\text { vízió }\end{array}$ & $\begin{array}{c}\text { CN vápa } \\
\text { revíziós }\end{array}$ & $\begin{array}{c}\text { CN vápa } \\
\text { primer }\end{array}$ & $\begin{array}{c}\text { vápa- } \\
\text { kosár + } \\
\text { cementes } \\
\text { vápa }\end{array}$ & $\begin{array}{c}\text { cemen- } \\
\text { tes } \\
\text { vápa }\end{array}$ & $\begin{array}{c}\text { vápa } \\
\text { augmen- } \\
\text { táció }\end{array}$ & $\begin{array}{c}\text { csak } \\
\text { vápa- } \\
\text { revízió }\end{array}$ & $\begin{array}{c}\text { csak } \\
\text { szárrevízió }\end{array}$ \\
\hline $\begin{array}{c}2001-2010 \\
442 \text { beteg }\end{array}$ & 0 & 16 & 243 & 82 & 0 & 72 & 117 \\
\hline $\begin{array}{c}2011-2017 \\
623 \text { beteg }\end{array}$ & 219 & 31 & 221 & 61 & $17 / 5$ & 136 & 91 \\
\end{tabular}

\section{MEGBESZÉLÉS}

Revíziók esetén sem cementes szár, sem cementes vápa beültetése a destruált csontfelszín és a csökkent csontállomány miatt az elégtelen cementezhetőség miatt nem szerencsés, salvage-ként alkalmazható. Ez alól kivétel, ha „impaction bone graft” technikát alkalmazunk, vagy elegendő spongiosus felszín áll rendelkezésre. Ez utóbbi esetben akár cementnélküli primer vápa, vagy Müller típusú cementnélküli primer szár is használható.

$\mathrm{Az}$ irodalmi adatok és a saját betegeink utánvizsgálata alapján megállapítható, hogy cementnélküli revíziós rendszerek használatával a revíziók minőségét jelentősen javíthatjuk $(14,18,22,24,25,40)$.

Cementnélküli kónikus Wagner szár beültetésével, az osteotomia nélküli centralizált-dilatációs fúrás technikával, a szár mind primer mind szekunder stabilitása a rehabilitációs időt csökkenti $(7,38)$.
Váparevíziók esetén a kihívás fokozottabb, különösen a Paprosky Illb vápadestrukciós esetekben (29). A revíziós implantátum rendszerek elmúlt évtizedben elért kimagasló fejlődése lehetővé tette a bonyolultabb esetek megbízható mútéti kezelését (27). Tapasztalatunk szerint a megfelelő felszínborítású, tantalum vápák alkalmazásával nemcsak a mútét válik jelentősen egyszerúbbé, de az implantátum primer, majd szekunder stabilitása is megbízhatóbb, szerényebb reziduális csontviszonyok mellett is $(23,27,28,30,34,39)$. Az implantátum csontos integrációja szövettanilag igazolt (13). Mindez a beteg előnyére gyorsabb rehabilitációt jelent. A problémát egyrészről az ovális típusú vápadestrukció jelentheti, amikor a vápamaráskor a nem elegendő PA csontviszony korlátozza a vápaméret növelését (21). Ilyen esetekben, amennyiben lehetséges, magasabb forgáscentrumba ültetjük a revíziós vápát. Más esetekben a felső hiányt augmentáljuk, szintén tantalum augmentációs implantátummal, majd 
alá beültetett szintén tantalum felszínű revíziós vápával, vagy vápakosár beültetésével csontőrlemény kiegészítéssel revideálunk (10. ábra). Ez egy kellően kompakt, némileg dinamikus, a cementes augmentációnál kevésbé rigid rendszer. Bár a rövidtávú eredmények bíztatóak, az implantátum kapcsolódás vonatkozásában a hosszú távú eredmények nem állnak rendelkezésre. Amikor lehetséges, contained esetben csontőrlemény és strukturális graft, uncontained esetekben strukturális graft beültetésével érhetünk el megbízható implantációt $(2,32,36,37)$. A hátsó felső fal hiánya,

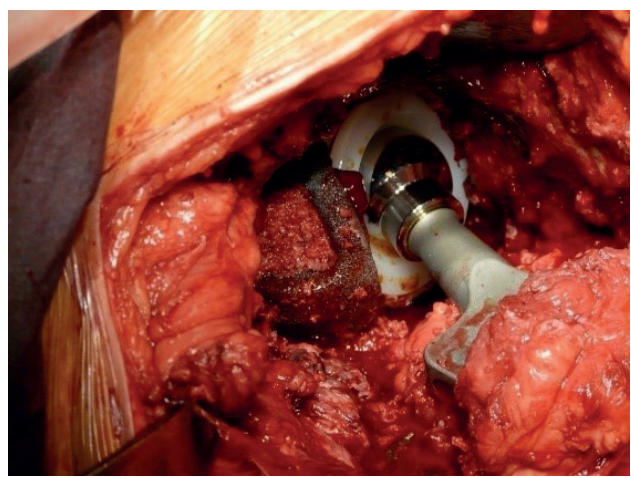

10. ábra TM augment csontörleménnyel kombinálva + TM shell vápa beültetés vagy a teljes medence inkontinuitás eseteiben a tantalum felszínú revíziós vápába helyezett úgynevezett "cup cage” jelentheti a megoldást (31) (11. ábra). A szekunder Girdlestone mútét esetleges indikációjáról soha nem szabad megfeledkezni. Bár a háttér revíziós arzenál szinte végeláthatatlan (12. ábra), minden esetben arra kell törekednünk, hogy a létező legbiologikusabb módon, a biomechanikát maximálisan szem előtt tartva revideáljunk úgy, hogy azt a beteg hosszútávon kielégítő életminőségben használni tudja.

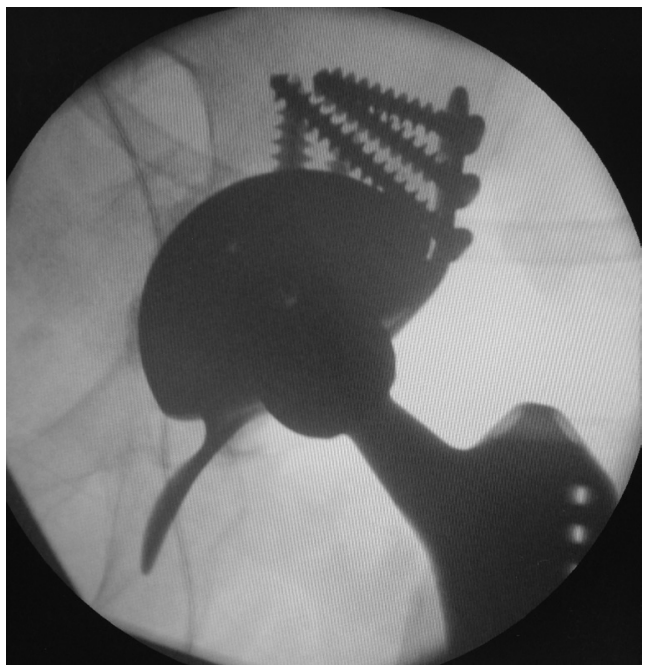

11. ábra Csípőprotézis revizió kiterjedt Plllb destrukcióban úgynevezett „cup cage” beültetésével

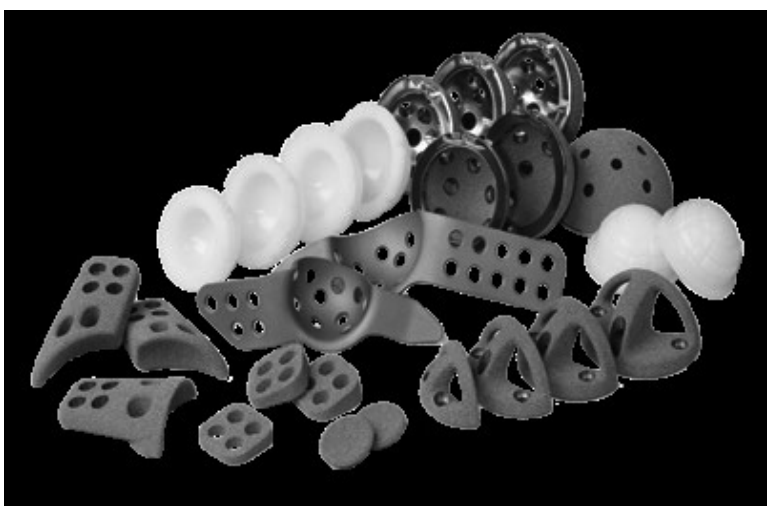

12. ábra Trabecular Metal Acetabular Revision System (TMARS) vápa revíziós implantátumok 


\section{IRODALOM}

1. Abolghasemian M., Tangsataporn S., Sternheim A., Backstein D., Safir O., Gross A. E.: Combined trabecular metal acetabular shell and augment for acetabular revision with substantial bone loss: A mid-term review. J. Bone Joint Surg. 2013. 95-B: 166-172. https://doi.org/10.1302/0301-620X.95B2.30608

2. Akiyama H., Morishama T., Takemoto M., Yamamoto K., Otsuka H., Iwase T., Kabata T., Soeda T., Kawanabe K., Sato K.: A novel technique for impaction bone grafting in acetabular reconstruction of revision total hip arthroplasty using an ex vivo compaction device. J. Orthop. Sci. 2011. 16. (1): 26-37. https://doi.org/10.1007/s00776-010-0007-1

3. Bozic K. J., Freiberg A. A., Harris W. H.: The high hip center. Clin. Orthop. Relat. Res. 2004. 420: 101-105. https://doi.org/10.1097/00003086-200403000-00014

4. Bradnock B., MacDonald R. A., Law H. T.: Is it necessary to remove all of the cement in revision hip surgery? J. Bone Joint Surg. 1990. 72-B: 739.

5. Callaghan J. J., Salvati E. A., Pellici P. M., Wilson P. D., Ranawat C. S.: Results of revision for mechanical failure after cemented total hip replacement, 1979 to 1982. J. Bone Joint Surg. Am. 1985. 67. (7): 1074-1085. https://doi.org/10.2106/00004623-198567070-00011

6. Chin A. K., Moll F. H., McColl M. B., Hoffman K. J., Wuh H. C. K.: An improved technique for cement extraction in revision total hip arthroplasty. Contemp. Orthop. 1991. 22. (3): 225-234.

7. Della Valle C. J., Berger R. A., Rosenberg A. G., Galante J. O.: Cementless acetabular reconstruction in revision total hip. Clin. Orthop. Relat. Res. 2004. 420: 96-100. https://doi.org/10.1097/00003086-200403000-00013

8. Della Valle C. J., Paprosky W. G.: Classification and an algorithmic approach to the reconstruction of femoral deficiency in revision total hip arthroplasty. J. Bone Joint Surg. Am. 2003. 85. (Suppl. 4): 1-6. https://doi.org/10.2106/00004623-200300004-00001

9. Dennis D. A., Dingman C. A., Meglan D. A., O'Leary J. F. M., Mallory T. H., Merme N.: Femoral cement removal in revision total hip arthroplasty. A biomechanical analysis. Clin. Orthop. Relat. Res. 1987. 220: 142-147.

10. Eftekhar N. S.: Rechannelization of cemented femur using a guide and drill system. Clin. Orthop. Relat. Res. 1977. 123: 2931. $h$ ttps://doi.org/10.1097/00003086-197703000-00011

11. Elganzoury I., Bassiony A. A.: Early results of trabecular metal augment for acetabular reconstruction in revision hip arthroplasty. Acta Orthop. Belg. 2013. 79. (5): 530-535.

12. Gruen T. A., Poggie R. A., Lewallen D. G., Hanssen A. D., Lewis R. J., O’Keefe T. J., Stulberg S. D., Sutherland C. J.: Radiographic evaluation of a monoblock acetabular component:A multicenter study with 2- to 5-year results. J. Arthroplasty. 2005.20. (3): 369-378. https://doi.org/10.1016/i.arth.2004.12.049

13. Hacking S. A., Bobyn J. D., Toh K., Tanzer M., Krygier J. J.: Fibrous tissue ingrowth and attachment to porous tantalum. J. Biomed. Mater. Res. 2000. 52. (4): 631-638. https://doi.org/10.1002/1097-4636(20001215)52:4<631::AID-JBM7>3.0.CO;2-6

14. Harris W. H.: Traumatic arthritis of the hip after dislocation and acetabular fractures: treatment by mold arthroplasty. An end-result study using a new method of result evaluation. J. Bone Joint Surg. Am. 1969. 51. (4): 737-755. https://doi.org/10.2106/00004623-196951040-00012

15. Hendricks K. J. Harris W. H.: High placement of noncemented acetabular in revision total hip arthroplasty. A concise followup, at a minimum of fifteen years, of a previous report. J. Bone Joint Surg. Am. 2006. 88. (10): 2231-2236.

16. Huang D. Y., Zhang L., Zhou Y., Zhang C. Y., Xu H., Huang Y.: Total hip arthroplasty using modular trabecular metal acetabular components for failed treatment of acetabular fractures: A mid-term follow-up study. Chin. Med. J. (Engl). 2016. 129. (8): 903-908. https://doi.org/10.4103/0366-6999.179793

17. Iorio R., Puskas B., Healy W. L., Tilzey J. F., Specht L. M., Thompson M. S.: Cementless acetabular fixation with and without screws: analysis of stability and migration. J. Arthroplasty, 2010. 25. (2): $309-313$. https://doi.org/10.1016/i.arth.2009.01.023

18. Joglekar S. B., Rose P. S., Lewallen D. G., Sim F. H.: Tantalum acetabular cups provide secure fixation in THA after pelvic irradiation at minimum 5-year followup. Clin. Orthop. Relat. Res. 2012. 470: 3041-3047. https://doi.org/10.1007/s11999-012-2382-8

19. Kamada T., Mashima N., Nakashima Y., Imai H., Takeba J., Miura H.: Mid-term clinical and radiographic outcomes of porous tantalum modular acetabular components for hip dysplasia. J. Arthroplasty. 2015. 30: 607-610. https://doi.org/10.1016/i.arth.2014.11.007

20. Kandala N. B., Connock M., Pulikottil-Jacob R., Sutcliffe P., Crowther M. J., Grove A., Mistry H., Clarke A.: Setting benchmark revision rates for total hip replacement: analysis of registry evidence. BMJ. 2015. 350: $h 756$. https://doi.org/10.1136/bmi.h756

21. Landor I., Vavrik P., Jahoda D., Pokorny D., Tawa A.: The Long Oblique Revision component in revision arthroplasty of the hip. J. Bone Joint Surg. Br. 2009. 91. (1): 24-30. https://doi.org/10.1302/0301-620X.91B1.20906

22. Macheras G. A., Kateros K., Koutsostathis S. D., Tsakotos G., Galanakos S., Papadakis S. A.: The trabecular metal monoblock acetabular component in patients with high congenital hip dislocation:A prospective study. J. Bone Joint Surg. Br. 2010. 92. (5): 624-628. https://doi.org/10.1302/0301-620X.92B5.23256

23. Macheras G. A., Papagelopoulos P. J., Kateros K., Kostakos A. T., Baltas D., Karachalios T. S.: Radiological evaluation of the metal-bone interface of a porous tantalum monoblock acetabular component. J. Bone Joint Surg. Br. 2006. 88. (3): 304309. https://doi.org/10.1302/0301-620X.88B3.16940 
24. Macheras G., Kateros K., Kostakos A., Koutsostathis S., Danomaras D., Papagelopoulos P. J.: Eight- to ten-year clinical and radiographic outcome of a porous tantalum monoblock acetabular component. J. Arthroplasty. 2009. 24. (5): 705-709. https://doi.org/10.1016/i.arth.2008.06.020

25. Meneghini R. M., Ford K. S., McCollough C. H., Hanssen A. D., Lewallen D. G.: Bone remodeling around porous metal cementless acetabular components. J. Arthroplasty. 2010. 25: 741-747. https://doi.org/10.1016/j.arth.2009.04.025

26. Meneghini R. M., Meyer C., Buckley C. A., Hanssen A. D., Lewallen D. G.: Mechanical stability of novel highly porous metal acetabular components in revision total hip arthroplasty. J. Arthroplasty. 2010. 25. (3): 337-341. https://doi.org/10.1016/i.arth.2009.03.003

27. Moore M. S., McAuley J. P., Young A. M., Engh C. A. Sr.: Radiographic signs of osseointegration in porous-coated acetabular components. Clin. Orthop. Relat. Res. 2006. 444: 176-183. https://doi.org/10.1097/01.blo.0000201149.14078.50

28. Noiseux N. O., Long W. J., Mabry T. M., Hanssen A. D., Lewallen D. G.: Uncemented porous tantalum acetabular components: Early follow-up and failures in 613 primary total hip arthroplasties. J. Arthroplasty. 2014. 29. (3): 617-620. https://doi.org/10.1016/j.arth.2013.07.037

29. Paprosky W. G., Perona P. G., Lawrence J. M., Acetabular defect classification and surgical reconstruction in revision arthroplasty J Arthroplasty. 1994. 9. (1): 33-44. https://doi.org/10.1016/0883-5403(94)90135-X

30. Ranawat A., Zelken J., Helfet D., Buly R.: Total hip arthroplasty for posttraumatic arthritis after acetabular fracture. J. Arthroplasty. 2009. 24. (5): 759-767. https://doi.org/10.1016/j.arth.2008.04.004

31. Rogers B. A., Whittingham-Jones P. M., Mitchell P. A., Safir O. A., Bircher M. D., Gross A. E.: The reconstruction of periprosthetic pelvic discontinuity. J. Arthroplasty. 2012. 27. (8): 1499-1506.e1. https://doi.org/10.1016/i.arth.2011.12.017

32. Schofer M. D., Pressel T., Schmitt J., Heyse T. J., Boudriot U.: Reconstruction of the acetabulum in THA using femoral head autografts in developmental dysplasia of the hip. J. Orthop. Surg. Res. 2011. 6: 32. https://doi.org/10.1186/1749-799X-6-32

33. Schurman D. J., Maloney W. J.: Segmental cement extraction at revision total hip arthroplasty. Clin. Orthop. Relat. Res. 1992. 285: 158-163. https://doi.org/10.1097/00003086-199212000-00021

34. Siegmeth A., Duncan C. P., Masri B. A., Kim W. Y., Garbuz D. S.: Modular tantalum augments for acetabular defects in revision hip arthroplasty. Clin. Orthop. Relat. Res. 2009. 467: 199-205. https://doi.org/10.1007/s11999-008-0549-0

35. Sporer S. M., Paprosky W. G.: The use of a trabecular metal acetabular component and trabecular metal augment for severe acetabular defects. J. Arthroplasty. 2006. 21. (6. Suppl. 2.): 83-86.

36. Udvarhelyi I.: Csípőizületi vápaplastikák TEP beültetés során. Doktori értekezés. Budapest. 1987.

37. Udvarhelyi I.: Vápatetöképzés sekély vápa pótlására csípőizületi arthroplastica során. Magyar Traumatológia Ortopédia Kézsebészet Plasztikai Sebészet, 1980. 23. 288-292.

38. Wagner H., Wagner M.: Femoral revision prosthesis in severe bone loss. Noncemented total hip replacement. In: Kusswetter W. (ed.): International symposium, Tubingen, 1990. Stuttgart, New York: Georg Thieme Verlag, 1991. 301-313. p.

39. Whitehouse M. R., Masri B. A., Duncan C. P., Garbuz D. S.: Continued good results with modular trabecular metal augments for acetabular defects in hip arthroplasty at 7 to 11 years. Clin. Orthop. Relat. Res. 2015. 473. (2): $521-527$. https://doi.org/10.1007/s11999-014-3861-x

40. Wroblewski B. M.: Revision surgery in total hip arthroplasty. London: Springer-Verlag. 1990. 179-199. p. https://doi.org/10.1007/978-1-4471-1788-9

41. Wyatt M., Hooper G., Frampton C., Rothwell A.: Survival outcomes of cemented compared to uncemented stems in primary total hip replacement. World J. Orthop. 2014. 5. (5): 591-596. https://doi.org/10.5312/wjo.v5.i5.591

\section{Dr. Udvarhelyi Iván}

Uzsoki Utcai Kórház Ortopéd-Traumatológiai Osztály

1145 Budapest, Uzsoki u. 29-41.

Tel.: 06 (1) 467-3700

E-mail: ivan.udvarhelyi@gmail.com 